\title{
Evaluation of merger premium and firm performance in Europe
}

\author{
Matthias Nnadi \\ School of Management, \\ Cranfield University, Bedfordshire, UK \\ Email: Matthias.nnadi@,cranfield.ac.uk
}

\author{
Daniel Aghanya \\ School of Management, \\ Cranfield University, Bedfordshire, UK \\ Email: Daniel.aghanya@cranfield.ac.uk
}

\begin{abstract}
This paper investigates whether the deal premium affects the performance of the acquiring firms in European mergers and acquisitions (M\&As) deals for the period 2000-2013. We find a significant reduction in short-term performance of the acquiring firms after the M\&As, reflecting the overpayment hypothesis. Our result also indicates that the negative effect on the performance of the acquiring firms is less pronounced in the long-term. The result confirms the synergy hypothesis and the existence of quadratic relationship between high premium and performance. Our findings are robust as we control for firm and time trends. The findings of our study have implications for companies engaging in acquisitions in Europe.
\end{abstract}

Keywords: mergers; premiums; performance; acquisition; Europe, returns

\section{Introduction}

The 2010s produced the greatest wave of mergers in global history. According to the Dealogic (2016) financial data, global mergers and acquisitions (M\&As) have grown substantially in size, frequency, and strategic importance from below $\$ 20$ billion in 1967 to about $\$ 5.05$ trillion in 2015. Several reasons highlight the motives behind M\&A deals. These include growth opportunities (Harrison, Hitt and Ireland, 2001), gaining value in response to regime shifts in an industry (Mitchell and Mulherin, 1986), managerial hubris (Roll, 1986), defensive tactic (Gorton, Kahl and Rosen, 2009), a means to take advantage of market misvaluation (Shleifer and Vishny, 2003), bankruptcy avoidance, increase diversification, and synergy (Halpern, 1983; Haleblian et al., 2009). Bower (2001) puts forth five reasons for acquisition decisions as: 
(1) reducing overcapacity in mature industries, (2) achieving economies of scale and scope through geographic roll-ups, (3) expanding new products or market power, (4) standing-in for research and development, and (5) inventing an industry by culling resources from industries whose boundaries are disappearing.

Whatever the motives behind the managers' actions, there is no consensus about the postacquisition performance of the merging firms as there are different contrasting results. Some studies provide evidence of significant negative returns for the acquiring firms (e.g., Kennedy and Limmick, 1996; Rau and Vermaelen, 1998; Fuller et al., 2002 and Moeller et al., 2005), as well as negative long run post-acquisition performance (Agrawal and Jaffe, 2000). Other studies (e.g., Franks et al., 1991) do not find significant underperformance post-acquisition. Antoniou et al. (2008) for example, examine the impact of premiums on the post-acquisition performance but find no evidence that high premium paying companies underperformed low premium paying ones in the three-years following the deal. Another stand of the M\&As literature shows the positive abnormal returns on these deals post-acquisition (e.g., HumpheryJenner and Powell, 2011), and Mulherin and Boone (2000) report a positive synergistic wealth effects after the acquisition. Similarly, Savor and Lu (2009) provide evidence that companies who successfully consummate a deal perform better than those who fail to do so.

Extant literature suggests that merger premiums are often overpaid (e.g., Schwert, 1996; Agrawal and Jaffe, 2000; Dong et al, 2006; Eckbo, 2009). For the target firms, the overwhelming evidence suggests that, on average, they earn positive abnormal returns in post M\&A deals (Datta, et al., 1992; Hansen and Lott, 1996; Chari et al., 2012, Goddard et al., 2012). This is largely attributable to the premiums received as part of the merger transaction. However, for the acquiring firms, the evidence is rooted within the contrasting literature of negative abnormal returns, non-significant underperformance and positive abnormal returns (see for example, Moeller et al., 2004; Antoniou et al., 2008; Savor and Lu, 2009). Given these trade-offs, the benefits of M\&A are not obvious. As a result, the association between premium and performance is largely an empirical matter. To provide evidence, the present study examines the relation between premiums paid and the short-term post-merger performances of acquiring firms in the EU.

We also analyse the effect of the takeover on the long-term post-merger performances of acquiring firms in the EU. Majority of the studies that examine merger premium and firm value focus mainly on the US and UK based firms. Given the global relevance of the EU and the 
growing M\&A deals in the region, there is need for more diverse study as research is scanty in this regard (see Papadakis, and Thanos, 2010). Consequently, the study of the impact of the EU M\&A deals will offer rich insights on the effect of M\&A on post-acquisition performance of the acquiring firms.

Our study is underpinned by two hypotheses, namely the overpayment and the synergy hypotheses. The first hypothesis posits that high premium paid during acquisitions is responsible for the subsequent underperformance of firms (e.g., Sung, 1993; Schwert, 2003). The theory hinges on the fact that high premiums could force managers to create impossible targets to justify the price paid for the target. If the expected targets are not met, then the takeover consequently destroys value. Jensen and Meckling (1976) argue that managers overpay for the target firms for their personal benefits; and Roll (1986) conjectures that managers' motivated by hubris tend to overpay for targets. The second hypothesis posits that the premium paid is a signal of the synergies expected (e.g., Harrison et al., 1991; Palia, 1993; $\mathrm{Fu}$ et al., 2013). The hypothesis argues that managers will pay higher premium for higher synergy values.

This paper contributes to extant literature by providing a comprehensive evidence of the effects of M\&A deals on short- and long-term performance of firms in the EU. In doing so, we control for deals, firm and country level characteristics that could influence the size of the premium offered in a deal. Our study differs substantially from existing studies. For example, Antoniou et al (2008) examine the difference in the performance of large versus low premium UK firms between 1984-2004 while our study focuses on large EU mergers and uses the Carhart fourfactor model to capture the momentum factor which is the earning premium of the acquirers. The momentum factor enables us to estimate the Alpha of the post deal completions for up to 60 months. We provide empirical evidence with more recent data of 2000-2013 on the impact of premium on short and long term performance by evaluating the existence of quadratic relationship between high premium and performance. Finally, our study also estimates the point of inflection between which the synergy hypothesis becomes effective.

Our results show a significant negative influence of the premium on the abnormal returns, supporting overpayment hypothesis (Grullon et al., 1997). The result suggests that the acquiring firms are paying higher premium on targets firms, higher than market participants' expectation, suggesting that the acquisitions are value destroying. Our findings also show that 
the quadratic relation predict that the market expects a value creating acquisition will command a higher premium, around two times the average premium - reflecting a synergy effect.

Further, our empirical results suggest that, indeed, the long-term performance of the acquisition is negative to the acquirers. Our results adds to the growing literature on long-term postacquisition underperformance of the bidder (e.g., Agrawal et al., 1992; Limmack, 1991; Loughran and Vijh, 1997; Rau and Vermaelen, 1998) by showing that the long-term takeover effect of EU firms are not value adding. In this regard, we contribute to the broader literature on the long-term performance of mergers (e.g., Rau and Vermaelen, 1998).

The rest of the paper is organised as follows: Section 2 is literature review and the development of the research hypotheses; Section 3 is the description of data and research models. Section 4 discusses the empirical tests and results of the study, and Sections 5 is conclusion.

\section{Literature review and hypotheses development}

The popularity of the performance of corporate acquisitions is increasing especially since the 1980s. As a result, the economic value of the acquisition for the acquiring firm has been the subject of interest to a significant number of practitioners and academia from different fields (Roll, 1986; Varian, 1988; Sudarsanam and Mahate, 2003; Zollo and Meier, 2008; Cho et al., 2016). Due to the complexity of the M\&As process (Larsson and Finkelstein, 1999), there is no agreement on the approach to be used on measuring the acquisition success; whether by the long-term event or the short-horizon event windows (Javidan et al., 2004). Zollo and Meier (2008) review 88 articles of the M\&A literature published between 1970 and 2006 and find that $41 \%$ of the papers use the short-term approach while $28 \%$ adopt the long-term methodological approach. According to MacKinlay (1997), short-term event studies reduce the effect of confounding events and are robust to different model specifications while Healy et al. (1992) document that they correlate with long-term performance measures. On the other hand, Zollo and Meier (2008) find no significant relation between the short-term event and other approaches. Clearly, the conflicting findings motivate us to use both the short-term and the long-term approach to analyse the effect of acquisition premiums on performance.

\subsection{Hypothesis development}

Several researchers have attempted to document the evidence of the gains of M\&As for the acquiring firms. For example, Nathan and O'Keefe (1989) provide empirical evidence that 
premiums increase with time, and show a negative relationship with the business cycle, measured by the S\&P index. Schwert (1996) in his study of 1,814 deals of US firms finds a correlation between the level of run-up in the target firm's share price pre-bid announcement and the level of the premium paid. In a more recent study, Madura et al. (2012) find evidence of a positive relationship between industry and macroeconomic factors and premiums paid. They show that the level of the premium is directly proportional to the level of growth of an industry, the capital liquidity present and the level of volatility.

The perception of managers of the level of synergy benefits from takeovers, whether in the short and long-terms, will determine the level of premium paid. Too large premiums raise the stakes for what level of synergy needs to be achieved in order to make the deal a value creating one. This follows from the synergy hypothesis. It therefore means that if companies overpay, the markets are likely to punish them more severely in negative abnormal returns compared to their peers. Damodaran (2005) points out that in order to arrive at the price to pay for a target, the level of synergies should be the difference between the value of the combined firm and the sum of the standalone values of both firms discounted at the appropriate rate that highlights the risk of those synergy cash flows. If the present value of the synergies is less than the premium paid, then the deal has destroyed value and the market will eventually identify this value loss and correct itself.

Other factors advanced as determining the level of the premium paid include deal characteristics such as deal value (Moeller et al, 2004), toehold (percentage of shares held in the target by the acquirer at announcement (Eckbo, 2009)), level of target hostility (Schwert, 2000), and method of payment (Myers and Majluf, 1984). However, others are of the contrary view of the benefits of M\&A (see Zollo and Meier, 2008). We conclude that since the impact is not obvious, the effects are subject to empirical validation. Thus, our first hypothesis considers whether the amount of premium paid has any significant effect on the short run performance of a firm. Based on the above discussion, we hypothesize in the alternate form:

Hypothesis 1: Premium paid has significant effect on short run performance.

Next, we analyse the data to determine whether quadratic relationship exist between the premium paid and acquirers' returns. We consider this association because as expected, if the premium is too high, we should expect a positive effect, as indicated in the synergy and 
overpayment hypotheses that identify a relationship in the opposite direction. According to the synergy hypothesis, a higher deal premium could be a sign of great expectation from the merger and the possibilities of obtaining synergies (Slusky and Caves, 1991). For example, Danone, the French dairy company that wants to acquire a North America's firm, White Wave Foods for $\$ 12.5$ bn, pays about 40 times the target company expected earnings in 2017 (Barber, 2016). Therefore, our second hypothesis seeks to explore the relationship between premium paid and returns, and states as:

Hypothesis 2: There is a significant quadratic relationship or synergy between the premium paid and acquirers' returns?

Despite the intention of mergers to generate both short and long-term economic values for shareholders (Ramaswamy and Waegelein 2003), the question, whether it can be sustained past the short-term prospects, remains elusive. Because managers undertake mergers with multiple motives in mind (Schweizer, 2005), they see the price paid as the true assessment of the target's net worth and thus the short-term event studies may not reflect the full impact of the mergers ( Zollo and Meier, 2008). Therefore, we examine the M\&A long-term overall acquisition performance. Harrison et al. (2005) show that using the short-term event window for M\&A performance evaluation could lead to wrong findings since they are not related to the economic value from the mergers.

Most studies on M\&As have argued that acquiring firms suffer long-term abnormal underperformance (Doukas and Travlos, 1988; Agrawal and Jaffe, 2000). For example, Datta and Puia (1995) document significant negative abnormal returns on the US acquiring firms. On the contrary, other studies critique the view of long-term underperformance of takeovers, and argue that it is inconsistent with the efficient markets hypothesis (Dutta and Jog, 2009), and the extent of the impact on stock price depends on the estimation techniques used to measure the return (Martynovaa and Renneboogb, 2008). A growing number of other empirical studies report long-term economic values for shareholders following takeovers (e.g., Ben-Amar and Andre, 2006; Martynova and Renneboog, 2008; Eckbo and Thorburn, 2009). For instance, Langetieg (1978) documents that post-acquisition performance of the acquiring firm is not significantly different from the control sample. Similarly, Bradley and Jarrell (1988) and Franks et al. (1991) do not find significant post-acquisition underperformance of the acquiring firm while Rahman and Limmack (2004) find positive change in long-term operating performance of acquirers of 
Malaysian firms. Also, Kumar and Bansal (2008) focus on India acquiring firms and find a significant improvement in post-merger profitability. Though Nnadi and Tanna, (2014) have established that cross border acquisitions create significant loss in shareholder value for the acquiring banks, and that profitability in the case of domestic mergers is driven by the level of risks, the long-term effects of M\&As are not a priori obvious. The impact can differ across countries and time. To provide evidence, we examine the long-term effects of post-acquisition performance on the acquiring firms. Thus, we develop the following hypothesis in the alternate form:

Hypothesis 3: M\&A has significant effect on long-term performance of acquiring firm.

\section{$3 \quad$ Data and methodology}

\subsection{Sample and data collection}

The data on mergers and acquisitions deals on EU firms is obtained from the SDC Platinum of Thomson Financial Securities Data Worldwide Mergers and Acquisitions Database. In obtaining the data, we apply the following criteria:

- Time period: From 2000 to 2013. This period was chosen to cover the gap in existing literature on this topic, it includes the period of the most recent financial crisis, and ensures we have up to three years post-acquisition performance information as at the research date.

- Markets: The focus of this research is the European market. We have restricted the sample to deals involving acquirers and acquisition targets domiciled in this region.

- Public status: To ensure we obtain company specific information on both acquirer and target, the sample is restricted to public companies in which the offer price is not missing. We also restricted the sample to those transactions in which the acquirer crossed the $50 \%$ shareholding threshold in consummating the transaction.

- Deals and deal size: We only include completed deals. To reduce the impact of noise in the sample, we restrict the deals obtained to those with value exceeding \$5 million threshold.

- Exclusions: Following Fama and French (1992), we exclude financial firms and utilities due to the impact of regulation and other peculiarities within these industries. We also exclude cross-border takeovers except if it is within the EU, and deals classified by 
Thomson Financial as rumours, repurchases, recapitalizations, or target solicitations. Further, we exclude sample if the bidding and target firms do not have accounting data available for at least one year prior to takeover.

Our stock return and accounting data was collected from DataStream database. Our final sample consists of 725 mergers and acquisitions transactions from 19 European countries over the period 2000-2013 was obtained applying these standard selection criteria.

\subsection{Methodology}

For our short-term analysis of the effect of premium on firm performance post-acquisition, we adopt the notion that stock prices reflect the amount of private information impounded into it through informed trading by arbitragers. As stock market participants obtain new and valuable information about the acquisition and appraise the firm's performance around the occurrence of the merger, it will reflect on the stock returns for the acquiring firm (e.g., see Gubbi et al., 2010; Morck et al., 2000), and this can be used to determine the abnormal return around the announcement day. Thus, we employ the event study method because it reflects stock market responses to the unexpected announced event (McWilliams and Siegel, 1997).

In order to analyse the responses of the market participants to the announcements, we compute the cumulative abnormal returns (CAR) over an event window following Brown and Warner (1985), defined as:

$$
C A R_{i t}=\sum_{t=1}^{\tau} A R_{i t}
$$

where $A R_{i t}=R_{i t}-\hat{R}_{i t}$

$R_{i t}$ is the actual return of the sample firm $R_{i}$ at time $\mathrm{t}$ and $\hat{R}_{i t}$ is the expected return for that firm in time, $t$. Fama (1998) highlights that given the assumption of efficient markets, the abnormal returns for firms should be zero. The efficient markets hypothesis also assumes that prices adjust rapidly to any change in information. Hence, in response to a merger or acquisition announcement, we expect the prices of the securities to adjust rapidly to the new information.

To measure the short-term market reactions to the proposed deal, we use the three-day and five-day event windows and the market model to estimate the CARs. The abnormal returns are 
computed for each company over the event window. The Alpha $(\alpha)$ and Beta $(\beta)$ for each acquiring company is obtained by regressing the returns of the company on the returns of the market over the event window t-360 to t-60 (calendar days). In order to sidestep the possibility of carrying over past abnormal results into the event window, estimated returns are obtained by multiplying the derived beta by the market return. To test our first hypothesis, we run the following regression model for the three-day and five-day event window:

CAR $=\alpha+\emptyset+\beta_{1}$ Premium $+\beta_{2}$ Acq Ttl Assets $+\beta_{3}$ TransValue $+\beta_{4}$ Tgt Market to Book + $\beta_{5}$ Tgt ROA $+\beta_{6}$ Acq Tobin $Q+\beta_{7}$ Acq Stock Rtn $+\beta_{8}$ LnGDP $+\beta_{9}$ Acq Market to Book + $\beta_{10}$ Acq Rtn Volatility $+\beta_{11}$ Tgt Ttl Assets $+\beta_{12}$ HighLowpremium Dummy + $\beta_{t}$ YearDummies $+\varepsilon$

In the model, CAR is our abnormal returns from equation (1), $\alpha$ is the intercept and $\varnothing$ is fixed firm effects. Following Ahern et al. (2015), we compute premium as the transaction value reported by SDC divided by the market value of the target four weeks before the announcement date. Following existing research, we include several controls variables designed to mitigate potentially confounding factors known to affect the acquisition performance. We control for firm size of target (Asquith et al., 1983), acquirer firm size, (Morck et al., 1990), tender offers (Rau and Vermaelen, 1998), market to book ratio for acquirer and target firm (Laamanen, 2007). We control for transaction value, past year stock return and return volatility, and country's size using natural logarithm of GDP (Ahern et al., 2015). We control for high premium transactions via dummy variable that equals 1 if the premium is higher than the median premium of the target return on assets, or 0 if otherwise (Kisgen et al., 2009). The variables are fully defined in Appendix 1.

Diaz, Azofra and Guiterrez (2009) explore banking takeovers in Europe and found a quadratic relationship between deals premiums and bidder returns. Their findings indicate that up to a threshold of $21 \%$, the premium has a positive impact on the returns and with premium proxying for anticipated synergies, a finding consistent with Antoniou et al (2008). It is the goal of this paper to shed light on the impact, if any, of premiums paid on subsequent performance, using this quadratic approach. The existing literature on the link between premiums and subsequent performance remains relatively scanty compared to for example, the determinants of the takeover premium. This research seeks to provide a robust look into the nature of the relationship between deal premiums and post-acquisition performance in the EU. We include 
premium squared in the model (Eq. 3) to ascertain if a quadratic relationship exists between premium and returns.

Therefore, in our second hypothesis, to explore the existence of the nonlinearity relationship between the deal premium and performance, we follow Diaz et al. (2009) model and use the quadratic regression approach:

$C A R=\alpha+\emptyset+\beta_{1}$ Premium $+\beta_{2}$ Premium $^{2}+\sum \beta_{n} X_{n}+\varepsilon$

where the maximum of the premium is estimated as:

$\frac{\text { Sreturns }}{\text { SPremium }}=\beta_{1}+2 \beta_{2}$ Premium $=0$

Premium $=\frac{\beta_{1}}{2 * \beta_{2}}$

Where: the dependent variable for (3), $\boldsymbol{C A R}$, represents the cumulative abnormal return of the acquiring company for the $[-1 ;+1]$ and $[-2 ;+2]$ and our main independent variable, Premium, is as defined in equation (2). $X_{n}$ is the vector of control variables in equation (2). Premium ${ }^{2}$ is a variable that captures the quadratic relationship between both variables and the dependent variable as defined in equation (2), often referred to as inverted "U-shapes" functional form in literature. From equation (5), we expect the relationship between the bidder's return and deal premium (that is, the point of inflection) to be convex, that is $\beta_{1}<0$ and $\beta_{2}>0$.

Next, we evaluate the post-merger performance using the calendar-time portfolio approach. This approach overcomes some of the problems associated with event study methods (Mitchell and Stafford, 2000) and a widely accepted approach for measuring the abnormal performance of firms (e.g., Comer et al., 2009; Morse et al, 2011). It has been well documented that stock prices 'fully incorporate' all available information (e.g., Bai et al., 2016), which include for the bidding firms, the deal premium. Thus, we use the Carhart (1997) four-factor model, an extension of Fama and French (1993) three-factor model to estimate the abnormal returns for the long-term net performance of the mergers because it explains a major portion of the variation in equity returns (for example, Artman et al., 2012). Hence, for every observation, we obtain the returns, $R_{i t}$, from DataStream database which are then used in the 4-factor equation (3) below to estimate the abnormal return.

$R_{i t}-R_{f t}=\alpha_{i}+\beta_{i}\left(R_{m t}-R_{f t}\right)+s_{i} S M B_{t}+h_{i} H M L_{t}+h_{i} W M L_{t}+\epsilon_{i t}$ 
Here, for each day $t, R_{i t}-R_{f t}$ is the excess return of the test stock, $R_{m t}-R_{f t}$ is the market portfolio excess return, $S M B_{t}$ is the size premium return factor, $H M L_{t}$ is the value premium return factor, WML equals the earning premium (momentum factor) as calculated by French (2016), $\alpha_{i}$ is the intercept of the model which represents the abnormal performance earned by manager, and $\epsilon_{i t}$ is the stochastic error term.

\section{Empirical tests and results}

In this section, we present empirical evidence on the effects of the deal premium on the bidding firms' performance.

\subsection{Descriptive statistics}

Table 1 presents descriptive statistics of our final sample by countries (Panel A) and across time (Panel B). The United Kingdom remains the country with the highest number of acquirers over the sample period with 230 reported acquisitions. The UK and France are the highestvolume acquirer countries (50\% of deals) while Hungary, Lithuania and Luxembourg are the least-volume acquirer countries (less than 1\%). France and the UK also reported a combined transaction value of $\$ 327 \mathrm{~m}$ (around $47 \%$ ) over the sample period. Table 1 also shows that there is no major difference in the mode of payment, and around $46 \%$ of the transactions are financed by using cash only. The literature suggests that more stock are used during periods of high market valuation, otherwise cash is used. As column (4) indicates, the deal premium for mergers in Lithuania and Luxembourg are 100\% higher than the sample median while in Netherlands, it is $69 \%$ higher than the sample premium. Hungary, Portugal, and Greece recorded the lowest deal premium paid below the sample mean in our sample period.

Panel B of Table 1 summaries the transactions in Europe by year. The table shows that acquisitions in Europe follow the same wave patterns of M\&A activity globally (Alexandridis et al, 2012). M\&A activities declined in 2001 due to the Dot-com crash of summer 2000, but gradually build-up and reached a record high in 2006 (see Alexandridis et al., 2012). The financial crisis of 2007 also led to progressive decline in the number of M\&A transactions in the intervening years.

[Insert Table 1 here] 
Figure 1 indicates the relationship between percentage of premium and the number of M\&A deals. Between year 2000 and 2006, it indicates that as number of deals rises, the premiums tend to rise and vice versa. The year 2000 has the highest number of deals in the figure which corresponds to the highest median premium observed in our sample. High median premiums are identified in the years of high market valuation and bubbles - 2000 and 2007. It appears that although the financial crisis started to affect merger activities in late 2007, the impact was felt the following year as the median premiums declined in 2008 to $21 \%$ and fluctuates between $20 \%$ and $25 \%$ in year 2009 to 2013. Such evidence supports the merger wave hypothesis of acquisition activity and justifies the inclusion of year dummies in the regression models investigating the relationship between premiums and post-acquisition performance.

Figure 1. M\&A Deal activities and Percentage Premium

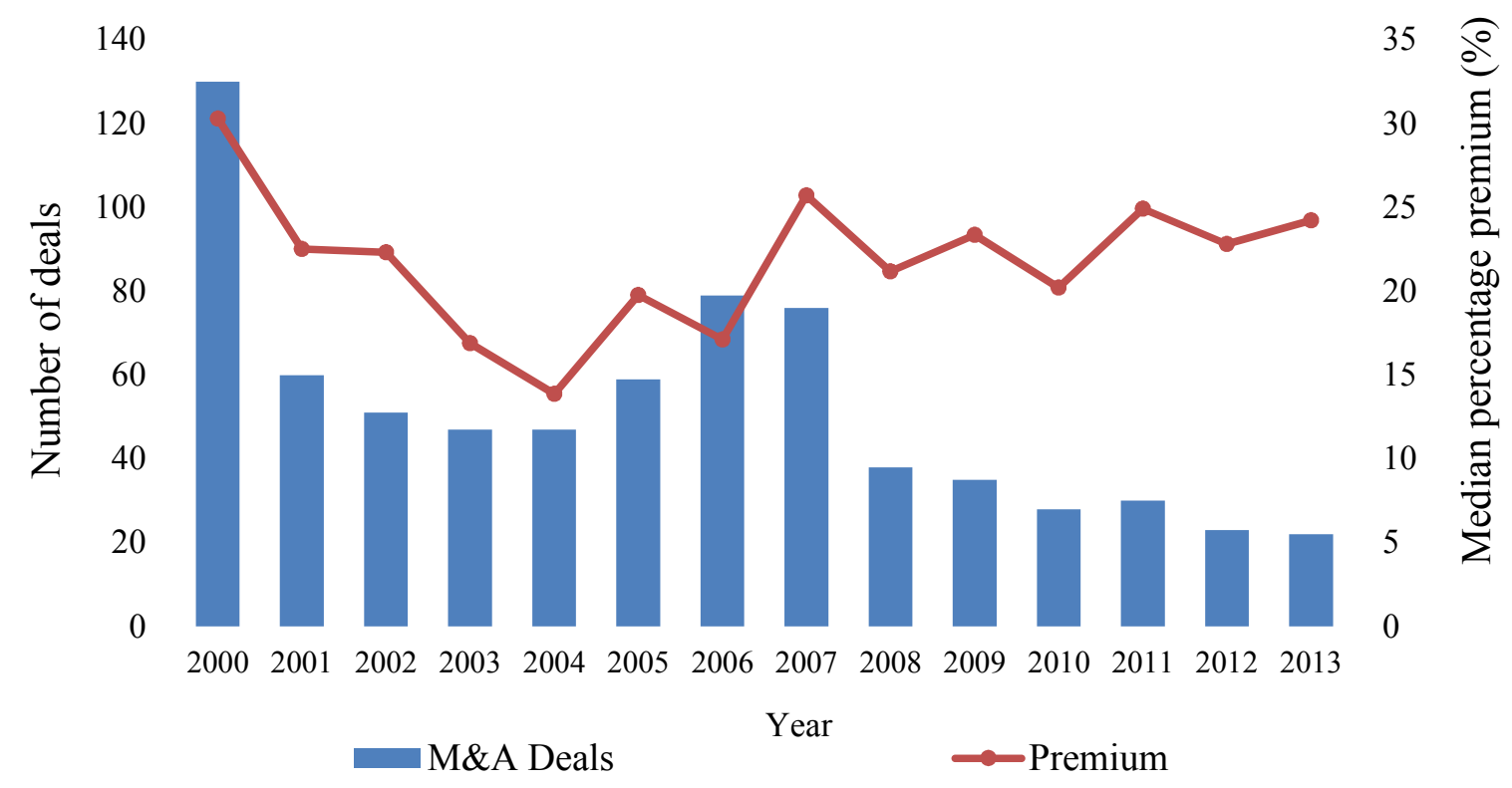

\subsection{The effects of premiums and post-merger performance using the short-term event window}

In this section, we examine the association of the impact of deals premium on the bidding firm performance after the merger. Using the market model, the 3- and 5- day CARs are analysed. Table 2 presents our primary results of the regression analyses. 
From the results in column (1), the 3-Day cumulative abnormal returns (CAR) without the fixed year effects is negative $\left(\beta_{1}=-0.184\right)$ and statistically significant at the $10 \%$ level, and in column (2), the results with the fixed year and firm effects is negative $\left(\beta_{1}=-0.185\right)$ and statistically significant at the $10 \%$ level. The results indicate that the premium paid has significant negative effect on the abnormal returns. In columns (3) and (4), using the 5-Day CARs as dependent variables, the results are not statistically significant. The results show that, on average, takeover of listed firms in the EU generates negative response from investors by producing negative abnormal returns to the bidding firms' shareholders. As shown from columns (1) to (4), the 5-Day [-2;+2] event is not significant but the 3-Day event window [$1 ;+1]$ is negative and statistically significant, suggesting that the arrival of new information allow investors to glean previously unavailable information, improving their investment decisions and informational efficiency of the capital markets. In addition, we find that high premium paying acquirers have a positive but insignificant CARs in the short window. In sum, the findings of the 3-Day regression results support hypothesis $\mathrm{H} 1$, which predict a negative association between premium paid and the bidding firm performance.

\section{[Insert Table 2 here]}

\subsection{Do mergers driven by higher premium generate synergies for the bidders?}

As discussed above, evidence suggests that the high premium paid by the acquirer generates negative response from shareholders and proxy for overpayment in takeovers, because as Dutordoir et al. (2014) argued, investors perceive that managers lack precise information to obtain accurate analysis of target synergy benefits. However, this association could be subject to size of the premium (see for example, Fu et al., 2013; Palia, 1993; Ruback, 1982). As the premium increases, investors could consider higher premium as evidence of higher synergy. Therefore, to test hypothesis $\mathrm{H} 2$, we analyse whether the magnitude of premium paid could influence the acquiring company's abnormal returns using a quadratic relationship.

Table 3 shows the results obtained from our regression analysis examining any quadratic relationship between the premium paid and acquirers' abnormal returns in the short run. It is observed in column (1) that the coefficient for Premium is negative and statistically significant at the 5\% level and the coefficient of Premium ${ }^{2}$ shows a significant positive association with abnormal returns at the $10 \%$ level. The findings confirm the existence of quadratic relation, but 
subject to the size of the premium. The coefficient of Premium is negative, supporting the overpayment hypothesis and suggesting that market participants consider acquisition as a value-destroying deal (Diaz et al., 2009; Mueller and Sirower, 2003). On the contrary, when the deal premium is very high, it has an insignificant but positive effect on the acquiring firm in line with the synergy hypothesis. The findings show that investors expect firms to be willing to pay above-average premiums for firms with relatively higher investment opportunities or for a special company that will help the acquiring company to get ahead of competitors such as through the realization of production and distribution economies. Ruback (1982) argues that a target firm that creates value should have several bidding firms competing for takeover and thus the acquiring firm will need to pay excessive high premium.

Next, analysing the quadratic relationship using the coefficients from Table 3 in column (1) and (2) on equation 5, the point of inflection should be between 3.01 (i.e, $-0.428 /(2 * 0.071)$ ) and 3.18 (i.e., $-0.414 /(2 * 0.065)$ ). Given that $\beta_{2}$ is positive in our estimates, these points represent the minimum. Taken at face value, these findings strongly suggest that investors will consider acquisition a value creating investment opportunity with substantial degree of synergies if the bidding firm pays above 2.01 to 2.18 times the average deal premium respectively, thus reflecting the effect of synergy hypothesis.

\section{[Insert Table 3 here]}

In columns (3) and (4) of Table 3, using the 5-Day abnormal return shows the regression results are not statistically significant. This suggests that lower information quality could affect stock prices leading to misvaluation of investments. In summary, using stock abnormal returns as proxy for post-acquisition value creation, the 3-Day regression results support our hypothesis $\mathrm{H} 2$ that there is a significant positive quadratic relationship between the premium paid and firm performance for the acquiring firm, suggesting synergy hypothesis. Further, these finding of the 3-Day and 5-Day also supports the notion of stock price informativeness, that the stock price reflects the amount of firm-specific information impounded into it.

\subsection{The effects of merger on the long-term performance of acquiring firm using the Calendar- time portfolio approach}

In this section, we analyse the effect of takeovers on the bidder's long-term performance using the Calendar-time portfolio approach used in prior studies (e.g., Dutta and Jog, 2009). To 
compute long run returns, we use the Carhart (1997) four-factor model to estimate the Alpha over the post deal completion. The CARs of each firm are regressed against the market premium, size and book to market factors over the respective months.

\section{[Insert Table 4 here]}

Table 4 reports the results of the calendar-time four-factor regression model. For the 12 months period, we observe a negative Alpha for the 2000-2013 period. The Alpha for the 12 months is negative and statistically significant $=0.35 \%$ per month, with a -statistic of 5.95 , though the abnormal returns are significantly below zero. Similarly, the intercept for the regression using the 24 months returns is negative and statistically significant $(\beta=-0.0014$, or $-0.14 \%)$. Therefore, our result shows underperformance of EU acquiring firms although the evidence from this analysis are barely below zero. The results are similar using the 36 months and 60 months returns. Therefore, our results show the long-term underperformance for EU acquiring firm and strengthens the inference from our findings that the EU acquiring firms are likely to result in long-term underperformance.

This finding is consistent with our short-term analysis. The coefficients of the SMB and HML factors are negative and are statistically significantly for most of the period. A negative coefficient of SMB implies that the average size of bidding firms is quite large while negative coefficient of HML suggests that the sample firms are high growth firms with higher price-tobook ratio and the positive coefficient of WML signifies that the sample firms past returns are marginally higher. The overall model fit is considerably lower (the largest adjusted $\mathrm{R}^{2}=0.09$ ). Collectively, by using both the short and long-term event window, we find strong support for the acquiring firm underperformance post-acquisition.

\section{$5 \quad$ Conclusion}

This study test three hypotheses which include whether premium paid has significant effect on the short run performance of the acquirers; examining if there is a significant quadratic 
relationship or synergy between the premium paid and the acquirers returns, and finally whether M\&As have significant effect on the long run performance of acquiring firms. The result of the first hypothesis shows that premium has a negative effect on the abnormal returns of acquirers. In our second hypothesis, the coefficient of premium is negative which supports the overpayment hypothesis and suggests that the market considers such acquisitions as value destroying. However, the premium ${ }^{2}$ has a positive and significant relationship with the CARs indicating existence of a quadratic relationship which also supports the synergy hypothesis. The result from our last hypothesis confirms that in the long run, European firms underperform following mergers and acquisition.

Our findings reveal that, in the short term, premiums have a negative quadratic relationship with abnormal returns and but a positive relationship in the long-term. Hence, in the short term, returns show a negative relationship with premium paid until a premium level of 2.01 times the average premium is reached. The overpayment hypothesis holds true until the 2.01 times the average premium mark is attained, after which the synergy hypothesis comes into play. Our result also confirms underperformance of acquirers after the merger.

These results are robust to several deal and firm specific characteristics. In this paper, we provides empirical evidence that as far as announcement period and long run post acquisition performance are concerned, premiums play a significant role in explaining the results obtained. The results do not necessarily imply causality but point to strong relationships between the variables. Low premium acquirers have an advantage as higher premiums paid creates a "hurdle" to cross; an extra motivation to actualise the synergies underpinning the premiums paid and this may invariably lead to their better performance.

The implication of these findings is that companies engaging in acquisitions need not worry about paying significant premiums if they can be certain of generating the synergies to justify the level of premium paid. In the same way as debt levels act as a hurdle to spur managers to deliver sufficient profits to meet interest and principal repayments, high premiums seem to act as a prod to managers of the acquiring company to deliver value in excess of the premium paid. Companies focusing on short run returns can offer significant premiums to excite the market about the synergies they think they can glean from the mergers. They would do well to remember that in the years following the acquisition, any failure to deliver on those forecasted synergies would be punished by the market though the operational cost efficiency and capital strength of acquirers are significant in influencing excess returns (Nnadi and Tanna, 2013). 
On the other hand, low premium acquirers while suffering only modest losses relative to peers in the announcement period must find the "motivation" to deliver synergy values beyond what their high premium counterparts would have done. The results show that they underperform their high premium paying counterparts and our study shows that high premium paying acquirers have an extra incentive, due to the level of premium already given to the target, to get back that value in synergies. Low premium acquirers must therefore benchmark against their high premium counterparts and seek to deliver similar levels of synergies. Only then can they argue to have preserved value over the short and long terms.

Taken together, the results obtained in the study show the need for more research on the impact of premium on post mergers and acquisitions using real accounting information. It would be interesting to analyse the impact of deal premium overpayment on corporate governance in the long term.

\section{Appendix}

Variable definition 


\begin{tabular}{|c|c|}
\hline Acq Market to Book & $\begin{array}{l}\text { This is the ratio of acquirer market-to-book value of equity the } 12 \\
\text { months prior to the announcement month (Source: DataStream). }\end{array}$ \\
\hline Acq Tobin Q & $\begin{array}{l}\text { Acquirer Tobin' q is measured as the market value (MV) of equity } \\
\text { less the book value (BV) of equity, plus the book value of assets, } \\
\text { all scaled by the book value of assets } 12 \text { months prior to the } \\
\text { announcement month (Source: DataStream). }\end{array}$ \\
\hline Acq Ttl Assets & $\begin{array}{l}\text { The natural logarithm of total assets of acquirer (Source: } \\
\text { DataStream). }\end{array}$ \\
\hline CAR & $\begin{array}{l}\text { This is a 3-day or 5-day abnormal market returns around earnings } \\
\text { announcement date estimated by using the market model (Source: } \\
\text { DataStream). }\end{array}$ \\
\hline HighLowpremium Dummy & $\begin{array}{l}\text { Dummy variable equal to one if premium is higher than the } \\
\text { median premium and zero otherwise }\end{array}$ \\
\hline Acq Rtn Volatility & $\begin{array}{l}\text { Acquirer Stock return volatility in the } 12 \text { months prior to the } \\
\text { announcement (Source: DataStream). }\end{array}$ \\
\hline Premium $^{2}$ & $\begin{array}{l}\text { is a variable that captures the quadratic relationship between } \\
\text { premium and CAR }\end{array}$ \\
\hline Acq Stock Rtn & $\begin{array}{l}\text { Acquirer Stock return in the } 12 \text { months prior to the announcement } \\
\text { month (Source: DataStream). }\end{array}$ \\
\hline LnGDP & $\begin{array}{l}\text { Natural logarithm of annual Gross Domestic Product (Source: } \\
\text { World Development Indicators). }\end{array}$ \\
\hline Premium & $\begin{array}{l}\text { Premium calculated as the transaction value reported by SDC } \\
\text { divided by the market value of the target four weeks before the } \\
\text { announcement date (Ahern et al., 2015). }\end{array}$ \\
\hline Tgt Market to Book & $\begin{array}{l}\text { This is the ratio of target firm market-to-book value of equity the } \\
12 \text { months prior to the announcement month (Source: } \\
\text { DataStream). }\end{array}$ \\
\hline Tgt ROA & $\begin{array}{l}\text { Target firm net income before the extraordinary items scaled by } \\
\text { total assets in the } 12 \text { months prior to the announcement month } \\
\text { (Source: DataStream). }\end{array}$ \\
\hline Tgt Ttl Assets & $\begin{array}{l}\text { The natural logarithm total assets of target firm (Source: } \\
\text { DataStream). }\end{array}$ \\
\hline TransValue & $\begin{array}{l}\text { The dollar value of all consideration paid in a merger (Source: } \\
\text { SDC). }\end{array}$ \\
\hline YearDummies & $\begin{array}{l}\text { Assigned dummy variables for each year to control for time } \\
\text { effects. }\end{array}$ \\
\hline
\end{tabular}

\section{References}


Agrawal, A. and Jaffe, J. F. (2000) 'The post-merger performance puzzle', in G. Cooper and A. Gregory, eds, JAI Series: Advances in Mergers and Acquisitions, Vol. 1, pp.7-41.

Agrawal, A., Jaffe, J. and Mandelker, G. (1992) 'The Post-Merger Performance of Acquiring Firms: A Re-examination of an Anomaly', Journal of Finance, Vol.47, pp.1605-1621.

Ahern, K., Daminelli, D. and Fracassi, C. (2015) 'Lost in translation? The effect of cultural values on mergers around the world', Journal of Financial Economics, Vo. 117, pp.165-189.

Alexandridis,G., Mavrovitis, C.F. and Travlos' N.G. (2012) 'How have M\&As changed? Evidence from the sixth merger wave', The European Journal of Finance, Vol. 18, No. 2, pp.663-688

Antoniou A., Arbour P. and Zhao H. (2008) 'How Much is Too Much: Are Merger Premiums Too High?', European Financial Management, Vol. 14, No. 2, pp.268-287.

Artmann, S., Finter, P. and Kempf, A. (2012) 'Determinants of expected stock returns: Large sample evidence from the German market', Journal of Business Finance and Accounting, Vol. 39, pp.758-784.

Asquith, P., Bruner, R. F. and Mullins, D. W. (1983) 'The gains to bidding firms from mergers', Journal of Financial Economics, Vol. 11, pp.121-139.

Bai, J., Philippon, T. and Savov, A. (2016) 'Have financial markets become more informative?', Journal of Financial Economics, Vol. 122, pp.625-654.

Barber, T. (2016). 'Acquisitive European groups pay high price for US expansion', FT.com, July 13. Available at: https://www.ft.com/content/bc3e073a-482a-11e6-8d68-72e9211e86ab (access: 13/04/2017).

Bower, J. (2001) 'Not All M\&As Are Alike — and That Matters', Harvard Business School: Working Knowledge. Available at: http://hbswk.hbs.edu/item/not-all-mas-are-alikeand-thatmatters (accessed 05 April 2017).

Bradley, M. and Jarrell, G. (1988) Comment, in John Coffee Jr., Louis Lowenstein, and Susan Rose-Ackerman, eds.: Knights, Raiders and Targets, Oxford University Press, Oxford, England, pp. 252-259.

Brown, S.J. and Warner, J. B. (1985) 'Using Daily Stock Returns: The Case of Event Studies', Journal of Financial Economics Vol. 14, pp.3-31.

Carhart, M. M. (1997) 'On Persistence in Mutual Fund Performance', The Journal of Finance, Vol. 52, pp.57-82.

Chari, A., Chen, W. and Dominguez, K. M. E. (2012) 'Foreign ownership and firm performance: Emerging market acquisitions in the United States', IMF Economic Review, Vol. 60, pp.1-42.

Cho, S., Arthurs, J., Townsend, D., Miller, D. and Barden, J. (2016) 'Performance deviations and acquisition premiums: the impact of CEO celebrity on managerial risk-taking", Strategic Management Journal', Vol. 37, pp.2677-2694.

Comer, G., Larrymore, N. and Rodriguez, J. (2009) 'Controlling for Fixed-Income Exposure in Portfolio Evaluation: Evidence from Hybrid Mutual Funds', The Review of Financial Studies, Vol. 22, pp.481-507. 
Damodaran A. (2005), The Value of Synergy, Working paper, available at SSRN: https://papers.ssrn.com/sol3/papers.cfm?abstract id $=841486$

Datta, D. and Puia, G. (1995) 'Cross-border acquisitions: an examination of the influence of related and cultural fit on shareholder value creation in US acquiring firms', Management International Review, Vol. 35, pp.337-359.

Datta, D., Pinches, G., and Narayanan, V. (1992) 'Factors Influencing Wealth Creation from Mergers and Acquisitions: A Meta-Analysis. Strategic Management Journal, Vol. 13, pp.6784.

Dealogic (2016) 'Global M\&A Review Full Year 2015', Dialogic, (January). Available at https://assets.documentcloud.org/documents/2704650/Dealogic-MA-Press-Release-FullYear-2015-FINAL.pdf. (accessed 17 April 2017)

Diaz, K.B., Azofra, S. and Gutierrez, L. (2009) 'Are M\&A Premiums Too High? Analysis of a Quadratic Relationship between Premiums and Returns', Quarterly Journal of Finance and Accounting, Vol. 48, No. 3, pp.5-21

Dong, M., Hirshleifer, D., Richardson, S. and Teoh, S. H. (2006) 'Does investor misvaluation drive the Takeover market?', Journal of Finance, Vol. 61, pp.725-762

Doukas, J. and Travlos, N. (1988) 'The effect of corporate multinationalism on shareholders' wealth: evidence from international acquisitions', Journal of Finance, Vol. 43, pp.401-417.

Dutordoir M., Roosenboom P. and Vasconcelos M. (2014) 'Synergy disclosures in mergers and acquisitions', International Review of Financial Analysis, Vol. 31, pp.88-100.

Dutta, S. and Jog, V. (2009) 'The long-term performance of acquiring firms: A reexamination of an anomaly', Journal of Banking and Finance, Vol. 33, No. 8, pp.1400-1412.

Eckbo, B. (2009) 'Bidding strategies and takeover premiums: A review', Journal of Corporate Finance, Vol. 15, pp. 149-178.

Eckbo, E. (2009) 'Bidding Strategies and Takeover Premiums: a Review', Journal of Corporate Finance, Vol. 15, pp.149-178.

Fama, E. and French, K., (1992) 'The cross-section of expected stock returns', Journal of Finance, Vol. 47, pp.427-465.

Fama, E. F. (1998) 'Market efficiency, long-term returns, and behavioural finance', Journal of Financial Economics, Vol. 49, pp.283-306

Fama, E. F. and French, K.R. (1993) 'Common risk factors in the returns on stocks and bonds', Journal of Financial Economics, Vol. 33, pp.3-56.

Franks, J., Harris, R. and Sheridan, T. (1991) 'The post-merger share price performance of acquiring firms', Journal of Financial Economics, Vol. 29, pp. 81-96.

French, K.R. (2016) Description of Fama/French Factors. Available at http://mba.tuck.dartmouth.edu/pages/faculty/ken.french/data library.html. (Accessed 18 April 2017)

Fu, F., Lin, L. and Officer, M. (2013) 'Acquisitions Driven by Stock Overvaluation: Are They Good Deals?' Journal of Financial Economics, Vol. 109, pp. 24-39. 
Fuller, K., Netter, J. M. and Stegemoller, M. (2002) 'What do returns to acquiring firms tell us? Evidence from firms that make many acquisitions, Journal of Finance, Vol. 57, pp.17631794.

Goddard, J., Molyneux, P., and Zhou, T. (2012) 'Bank mergers and acquisitions in emerging markets: Evidence from Asia and Latin America', European Journal of Finance, Vol. 18, pp.419-438.

Gorton, G., Kahl M., and Rosen R. (2009) 'Eat or Be Eaten: A Theory of Mergers and Firm Size', Journal of Finance, Vol. 64, No. 3, pp.1291-1344.

Grullon, G., Michaely, R. and Swary, I. (1997) 'Capital adequacy, bank mergers, and the medium of payment', Journal of Business, Finance \& Accounting, Vol. 24, pp. 97-124.

Gubbi, S., Aulakh, P., Pay, S., Sarkar, M., \& Chittoor, R. (2010) 'Do international acquisitions by emerging-economy firms create shareholder value: the case of India firms', Journal of International Business Studies, Vol. 41, No. 3, pp.391-418.

Haleblian, J., Devers, C., McNamara, G., Carpenter, M. and Davison, R., (2009) 'Taking Stock of What We Know About Mergers and Acquisitions: A Review and Research Agenda, Journal of Management, 35, pp. 469-502.

Halpern, P. (1983) 'Discussion', The Journal of Finance, Vol. 38, pp. 433-434.

Hansen, R. and Lott, J. (1996) 'Externalities and Corporate Objectives in a World with Diversified Shareholder/Consumers', The Journal of Financial and Quantitative Analysis, Vol. 31, pp. 43-68.

Harrison, J. S., Oler, D. and Allen, M. R. (2005) 'Event studies and the importance of longerterm measures in assessing the performance outcomes', In Zollo, M., and Meier, D., (2008) 'What is M\&A performance?', Academy of Management Perspective, Vol. 22, pp.55-77.

Harrison, J.S., Hitt, M.A. and Ireland, D.R. (2001) 'Resource complementarity in business combinations: Extending the logic to organizational alliances', Journal of Management, Vol. 27, pp. 679-690.

Harrison, J.S., Hitt, M.A., Hoskisson, R. and Ireland, D.R. (1991) 'Synergies and PostAcquisition Performance: Differences versus Similarities in Resource Allocations', Journal of Management, Vol. 17, pp.173-190.

Healy, P., Palepu, K. and Ruback, R. (1992) 'Does corporate performance improve after mergers?' Journal of Financial Economics, Vol. 31, pp. 135-175.

Humphery-Jenner, M. and Powell, R. (2011) 'Firm size, takeover profitability, and the effectiveness of the market for corporate control: Does the absence of anti-takeover provisions make a difference?' Journal of Corporate Finance, Vol. 17, pp.418-437 Javidan, M., Pablo A, Singh, H., Hitt, M. and Jemison, D. (2004) 'Where we've been and where we're going', In Mergers and Acquisitions: Creating Integrative Knowledge, Pablo A, Javidan, M. (eds) Blackwell: Oxford, UK, pp.245-261.

Jensen, M. and Meckling, W. (1976) 'Theory of the firm: Managerial behavior, agency costs and ownership structure', Journal of Financial Economics, Vol. 3, pp. 305-360. 
Kennedy, V. A. and Limmack, R. J., (1996) 'Takeover activity, CEO turnover, and the market for corporate control', Journal of Business Finance and Accounting, Vol. 23, pp.267-285.

Kisgen, D., Qian, J. and Song, W. (2009) 'Are fairness opinions fair? The case of mergers and acquisitions', Journal of Financial Economics, Vol. 91, pp.179-207.

Kumar, S., Bansal, L.K. (2008) 'The impact of mergers and acquisitions on corporate performance in India', Managerial Decisions, Vol. 46, pp.1531-1543.

Laamanen, T. (2007) 'On the role of acquisition premium in acquisition research', Strategic Management Journal, Vol. 28, pp. 1359-1369.

Langetieg, Terence C, 1978, 'An application of a three-factor performance index to measure stockholder gains from merger', Journal of Financial Economics, Vol. 6, pp.365-383.

Larsson, R. and Finkelstein, S. (1999) 'Integrating strategic, organizational, and human resource perspectives on mergers and acquisitions: a case survey of synergy realization', Organization Science, Vol. 10, No. 1, pp.1-26.

Limmack, R.J. (1991) 'Corporate Mergers and Shareholder Wealth Effects: 1977-1986', Accounting and Business Research, Vol. 21, pp.239-251.

Loughran, T. and Vijh, A. (1997) 'Do Long-Term Shareholders Benefit from Corporate Acquisitions', Journal of Finance, Vol. 52, pp.1765-1790.

MacKinlay, A. (1997) 'Event studies in economics and finance', Journal of economic literature, Vol. 35, No. 1, pp.13-39.

Madura J., Ngo T., \& Viale A. M. (2012) 'Why do merger premiums vary across industries and over time?', Quarterly Review of Economics and Finance, Vol. 52, pp.49-62

Martynovaa, M. and Renneboogb, L. (2008) 'A century of corporate takeovers: What have we learned and where do we stand?', Journal of Banking and Finance, Vol. 32, No. 10, pp.2148-2177.

McWilliams, A., \& Siegel, D. (1997) 'Event studies in management research: theoretical and empirical issues', The Academy of Management Journal, Vol. 40, No. 3, pp.626-657.

Mitchell, M. and Mulherin, H. (1986) 'The Impact of Industry Shocks on Takeover and restructuring Activity', Journal of Financial Economics, Vol. 41, 193-229.

Mitchell, M. and Stafford, E. (2000) 'Managerial Decisions and Long-Term Stock Price Performance', The Journal of Business, vol. 73, pp. 287-329.

Moeller, S .B., Schlingemannb, F.P. and Stulz, R.M. (2004) 'Firm size and the gains from acquisition', Journal of Financial Economics, Vol. 73, pp.201-228

Moeller, S. B., Schlingemann, F. P. and Stulz, R. M. (2004) 'Firm size and the gains from acquisitions', Journal of Financial Economics, Vol. 73, pp. 201-228.

Morck, R., Shleifer, A., and Vishny, R. W. (1990) 'Do managerial objectives drive bad acquisitions?', Journal of Finance, Vol. 45, No. 1, pp.31-48.

Morse, A., Nanda, V. and Seru, A. (2011) 'Are Incentive Contracts Rigged by Powerful CEOs?', Journal of Finance, Vol. 66, No. 5, pp.1887-1934. 
Mueller, D.C. and Sirower, M.L. (2003) 'The causes of mergers, Tests based on the gains to acquiring firms shareholders and the size of premia', Managerial and Decision Economics, Vol. 24, pp.373-391.

Mulherin, H. and Boone, A. (2000) 'Comparing Acquisitions and Divestitures', Journal of Corporate Finance, Vol. 6, pp.117-139.

Myers, S.C. and Majluf, N. (1984) 'Corporate financing and investment decisions when firms have information that investors do not have', Journal of Financial Economics, Vol. 13, pp.187221.

Nathan, K.S. \& O'Keefe, T.B. (1989) 'The Rise in Takeover Premiums: An Exploratory Study', Journal of Financial Economics, Vol. 23, pp.101-119

Nnadi, M. and Tanna, S. (2014) Post-acquisition profitability of banks: a comparison of domestic and cross-border acquisitions in the European Union. Global Business and Economics Review, Vol. 16, No. 3, pp. 310- 331

Nnadi, M. and Tanna, S. (2013) Analysis of cross-border and domestic mega-M\&As of European commercial banks. Managerial Finance, Vol. 39 Issue: 9, pp.848-862

Palia, D. (1993) 'The Managerial, Regulatory, and Financial Determinants of Bank Merger Premiums', The Journal of Industrial Economics, Vol. 41, pp. 91-102.

Papadakis, V. and Thanos, I. (2010) 'Measuring the Performance of Acquisitions: An Empirical Investigation Using Multiple Criteria', British Journal of Management, Vol. 21, pp. 859-873.

Rahman, R.A., Limmack, R.J., (2004) 'Corporate acquisitions and the operating performance of Malaysian companies', Journal of Business Finance and Accounting, Vol31, pp. 359-400.

Ramaswamy, K. and Waegelein, J. (2003) 'Firm financial performance following mergers', Review of Quantitative Finance and Accounting, Vol.20, pp.115-126.

Rau, P. and Vermaelen, T. (1998) 'Glamour, value and the post- acquisition performance of acquiring firms', Journal of Financial Economics, Vol. 49, No. 2, pp.223- 253

Roll, R. (1986) 'The Hubris Hypothesis of Corporate Takeovers', Journal of Business, Vol. 59, No. 2, pp.197-216.

Ruback, R. (1982) 'The Conoco takeover and stockholder returns', Sloan Management Review, Val. 23, pp.13-33.

Savor P. and Lu Q. (2009) 'Do Stock Mergers Create Value for Acquirers?', The Journal of Finance, Vol. 64, pp.1061-1097

Schweizer, L. (2005) 'Organizational integration of acquired biotechnology companies into pharmaceutical companies: the need for a hybrid approach', Academy of Management Journal, Vol. 48, No. 6, pp.1051-1074.

Schwert, G. W. (1996) 'Markup pricing in mergers and acquisitions', Journal of Financial Economics, Vol. 41, pp.153-192 
Schwert, G. W. (2000) 'Hostility in takeovers: In the eyes of the beholder?' Journal of Finance, Vol. 55, No. 6, pp.89-97

Schwert, G.W. (2003) 'Anomalies and market efficiency', In Handbook of the Economics of Finance, Constantinides, G.M., Harris, M. and Stulz, R. (eds.), Elsevier B.V.: North Holland, pp. 939-972.

Slusky, A. and Caves, R.E. (1991) 'Synergy, agency and the determinants of premia paid in mergers', Journal of Industrial Economics, Vol.39, pp.277-296.

Sudarsanam, S. and Mahate, A. (2003) 'Glamour Acquirers, Method of Payment and Postacquisition Performance: The UK Evidence, Journal of Business Finance \& Accounting, Vol. 30, pp.299-341.

Sung, H. (1993) 'The Effects of Overpayment and Form of Financing on Bidder Returns in Mergers and Tender Offers', The Journal of Financial Research, Vol. 16, pp. 351-365.

Varian, H. (1988) 'Symposium on takeovers', Journal of Economic Perspectives, Vol. 2, pp. 3-5.

Zollo, M., and Meier, D., (2008) 'What is M\&A performance?', Academy of Management Perspective, Vol. 22, pp.55-77.

\section{Table 1 (Panel A): Summary statistics: Sorted by country}

The sample consists of acquisitions taking place by European acquirers between 2000 and 2013. Premium is computed as the difference between the initial offer price and the target market price four weeks before the announcement date divided by the target market price four weeks before the announcement. Cash and Stock represent the number of deals with each 


\begin{tabular}{|c|c|c|c|c|c|c|c|}
\hline \multirow[b]{2}{*}{ Acquirer Country } & & & & \multicolumn{3}{|c|}{ Form of payment } & \multirow[b]{2}{*}{$\begin{array}{l}\text { Transaction } \\
\text { value }(\$ \mathrm{~m})\end{array}$} \\
\hline & $\begin{array}{l}\text { of } \\
\text { Deals }\end{array}$ & $\begin{array}{l}\text { Average } \\
\text { Premium (\%) }\end{array}$ & $\begin{array}{r}\text { High } \\
\text { Premium }\end{array}$ & Cash & Stock & Hybrid & \\
\hline Austria & 9 & 20 & 4 & 7 & 2 & 0 & 6,529 \\
\hline Belgium & 17 & 24 & 13 & 9 & 5 & 4 & 26,278 \\
\hline Finland & 19 & 31 & 11 & 10 & 4 & 5 & 5,415 \\
\hline France & 132 & 27 & 95 & 67 & 36 & 37 & 168,394 \\
\hline Germany & 55 & 21 & 33 & 35 & 12 & 9 & 57,812 \\
\hline Greece & 15 & 12 & 8 & 6 & 8 & 4 & 7,692 \\
\hline Hungary & 1 & 10 & 1 & 1 & 0 & 0 & 242 \\
\hline Ireland & 7 & 28 & 4 & 1 & 4 & 2 & 1,698 \\
\hline Italy & 37 & 24 & 20 & 16 & 10 & 12 & 58,255 \\
\hline Lithuania & 1 & 67 & 1 & 0 & 1 & 0 & 180 \\
\hline Luxembourg & 1 & 50 & 1 & 1 & 0 & 1 & 447 \\
\hline Netherlands & 29 & 40 & 22 & 19 & 5 & 4 & 30,045 \\
\hline Norway & 31 & 22 & 20 & 16 & 8 & 9 & 19,454 \\
\hline Poland & 11 & 17 & 6 & 4 & 3 & 6 & 2,292 \\
\hline Portugal & 3 & 6 & 3 & 3 & 0 & 0 & 644 \\
\hline Spain & 33 & 15 & 21 & 14 & 18 & 5 & 69,046 \\
\hline Sweden & 58 & 58 & 49 & 31 & 19 & 18 & 24,699 \\
\hline Switzerland & 36 & 28 & 24 & 24 & 9 & 4 & 60,230 \\
\hline United Kingdom & 230 & 32 & 178 & 118 & 70 & 61 & 158,777 \\
\hline Total & 725 & 30 & 514 & 382 & 214 & 181 & 698,129 \\
\hline
\end{tabular}

\section{Table 1 (Panel B): Summary statistics: Sorted by time period}

The sample consists of acquisitions taking place by European acquirers between 2000 and 2013 . Premium is computed as the difference between the initial offer price and the target market price four weeks before the announcement date divided by the target market price four weeks before the announcement. Cash and Stock represent the number of deals with each method. Hybrid means a 
combination of cash and stock. High premium is where the transaction value reported by SDC is higher than the market value of the target, four weeks before the announcement date.

\begin{tabular}{|l|r|r|r|r|r|r|r|}
\hline & & & & \multicolumn{2}{|c|}{ Means of Payment } & \\
\hline $\begin{array}{l}\text { Acquirer } \\
\text { Date }\end{array}$ & $\begin{array}{l}\text { No. of } \\
\text { Deals }\end{array}$ & $\begin{array}{l}\text { Average } \\
\text { Premium (\%) }\end{array}$ & $\begin{array}{r}\text { High } \\
\text { Premium }\end{array}$ & Cash & Stock & Hybrid & \multicolumn{2}{l|}{$\begin{array}{l}\text { Transaction } \\
\text { value (\$m) }\end{array}$} \\
\hline 2000 & 130 & 35 & 81 & 63 & 41 & 26 & 113,233 \\
\hline 2001 & 60 & 23 & 30 & 28 & 14 & 18 & 38,480 \\
\hline 2002 & 51 & 28 & 27 & 26 & 12 & 13 & 42,424 \\
\hline 2003 & 47 & 55 & 21 & 16 & 18 & 13 & 35,167 \\
\hline 2004 & 47 & 16 & 14 & 23 & 11 & 13 & 47,151 \\
\hline 2005 & 59 & 22 & 27 & 23 & 24 & 12 & 75,702 \\
\hline 2006 & 79 & 19 & 30 & 35 & 24 & 20 & 93,717 \\
\hline 2007 & 76 & 31 & 41 & 37 & 16 & 23 & 105,981 \\
\hline 2008 & 38 & 26 & 18 & 18 & 9 & 11 & 30,394 \\
\hline 2009 & 35 & 33 & 18 & 14 & 17 & 4 & 7,941 \\
\hline 2010 & 28 & 22 & 15 & 13 & 6 & 9 & 27,183 \\
\hline 2011 & 30 & 28 & 17 & 14 & 7 & 9 & 21,101 \\
\hline 2012 & 23 & 37 & 11 & 9 & 9 & 5 & 28,077 \\
\hline 2013 & 22 & 31 & 13 & 11 & 6 & 5 & 31,579 \\
\hline Total & $\mathbf{7 2 5}$ & $\mathbf{2 9}$ & $\mathbf{3 6 3}$ & $\mathbf{3 3 0}$ & $\mathbf{2 1 4}$ & $\mathbf{1 8 1}$ & $\mathbf{6 9 8 , 1 2 9}$ \\
\hline
\end{tabular}

\section{Table 2: The effect of deal premium on post-merger performance of bidding firms}

This table reports deal premium on firm performance post-acquisition. The dependent variables are cumulative abnormal returns for 3-Day (columns (1) and (2)) and 5-Day (columns (3) and (4)) event window . All variables (except High/Low premium dummy variable) are truncated at the 1st and 99th 
percentile. We include year and fixed effects to control for any fundamental differences in premium and controls across time. Estimated standard errors are robust to heteroskedasticity and clustered at the firm level. Statistically significance denoted as $* * *, * *$, and $*$ for $1 \%, 5 \%$ and $10 \%$ respectively (using a twosided test).

\begin{tabular}{|c|c|c|c|c|}
\hline & 1 & 2 & 3 & 4 \\
\hline & 3-Day CAR & 3-Day CAR & 5-Day CAR & 5-Day CAR \\
\hline \multirow[t]{2}{*}{ Premium } & $-0.184^{*}$ & $-0.185^{*}$ & -0.102 & -0.101 \\
\hline & {$[-1.77]$} & {$[-1.67]$} & {$[-0.80]$} & {$[-0.80]$} \\
\hline \multirow[t]{2}{*}{ Acq Market-to-Book } & 0.079 & 0.093 & -0.147 & -0.216 \\
\hline & {$[0.33]$} & {$[0.53]$} & {$[-0.68]$} & {$[-0.90]$} \\
\hline \multirow[t]{2}{*}{ Tgt Market-to-Book } & -0.015 & -0.050 & 0.006 & 0.003 \\
\hline & {$[-0.17]$} & {$[-0.58]$} & {$[0.05]$} & {$[0.03]$} \\
\hline \multirow[t]{2}{*}{ Ln(Acq Total Assets) } & 0.001 & $0.322 *$ & -0.155 & -0.161 \\
\hline & {$[0.01]$} & {$[1.76]$} & {$[-1.26]$} & {$[-0.83]$} \\
\hline \multirow[t]{2}{*}{ Ln(Tgt Total Assets) } & -0.058 & -0.069 & -0.035 & -0.034 \\
\hline & {$[-0.78]$} & {$[-1.08]$} & {$[-0.49]$} & {$[-0.50]$} \\
\hline \multirow[t]{2}{*}{ Ln(Transaction Value) } & 0.083 & 0.053 & 0.031 & 0.020 \\
\hline & {$[1.08]$} & {$[0.77]$} & {$[0.50]$} & {$[0.33]$} \\
\hline \multirow[t]{2}{*}{ Tgt ROA } & -0.001 & -0.002 & -0.001 & 0.000 \\
\hline & {$[-0.31]$} & {$[-0.64]$} & {$[-0.18]$} & {$[0.05]$} \\
\hline \multirow[t]{2}{*}{ High/Low premium } & 0.053 & 0.058 & 0.145 & 0.137 \\
\hline & [0.49] & {$[0.52]$} & [0.98] & {$[0.93]$} \\
\hline \multirow[t]{2}{*}{ Ln(Acq Past year return) } & 0.03 & -0.105 & -0.121 & -0.143 \\
\hline & {$[0.20]$} & {$[-0.68]$} & {$[-0.56]$} & {$[-0.58]$} \\
\hline \multirow{3}{*}{$\begin{array}{l}\text { Ln(Acq Past year return } \\
\text { volatility) }\end{array}$} & & & & \\
\hline & 0.252 & 0.346 & -0.329 & -0.166 \\
\hline & {$[0.53]$} & {$[0.59]$} & {$[-0.54]$} & {$[-0.27]$} \\
\hline \multirow[t]{2}{*}{ Acq Tobin Q } & -0.181 & -0.244 & -0.022 & -0.098 \\
\hline & {$[-0.72]$} & {$[-1.01]$} & {$[-0.07]$} & {$[-0.35]$} \\
\hline \multirow[t]{2}{*}{$\operatorname{Ln}(\mathrm{GDP})$} & -1.429 & -2.556 & -0.691 & -1.172 \\
\hline & {$[-0.52]$} & {$[-0.89]$} & {$[-0.18]$} & {$[-0.32]$} \\
\hline \multirow[t]{2}{*}{ Constant } & 6.86 & 8.152 & 5.897 & 8.548 \\
\hline & {$[0.51]$} & {$[0.62]$} & {$[0.33]$} & {$[0.50]$} \\
\hline Number of observations & 707 & 707 & 707 & 707 \\
\hline Adj. R-squared (\%) & 1.1 & 16.5 & 3.4 & 12.7 \\
\hline Year fixed effects & No & Yes & No & Yes \\
\hline Firm fixed effects & Yes & Yes & Yes & Yes \\
\hline
\end{tabular}




\section{Table 3: Relationship between the premium paid and acquirers' returns}

This table reports whether a quadratic relationship exists between the premium paid and acquirers' returns using deal premium on firm performance post-acquisition. The dependent variables are cumulative abnormal returns for 3-Day (columns (1) and (2)) and 5-Day (columns (3) and (4)) event window. All variables (except High/Low premium dummy variable) are truncated at the 1st and 99th percentile. We include year and fixed effects to control for any fundamental differences in premium and controls across time. Estimated standard errors are robust to heteroskedasticity and clustered at the firm level. Statistically significance denoted as $* * *, * *$, and * for $1 \%, 5 \%$ and $10 \%$ respectively (using a two-sided test).

\begin{tabular}{|c|c|c|c|c|}
\hline & 1 & 2 & 3 & 4 \\
\hline & 3-Day CAR & 3-Day CAR & 5-Day CAR & 5-Day CAR \\
\hline \multirow[t]{2}{*}{ Premium } & $-0.428 * *$ & $-0.414 * *$ & 0.162 & 0.204 \\
\hline & {$[-2.22]$} & {$[-2.03]$} & {$[0.53]$} & {$[0.70]$} \\
\hline \multirow[t]{2}{*}{ Premium Square } & $0.071^{*}$ & $0.065^{*}$ & -0.077 & -0.087 \\
\hline & {$[1.87]$} & {$[1.67]$} & {$[-1.23]$} & {$[-1.41]$} \\
\hline \multirow[t]{2}{*}{ Acq Market-to-Book } & 0.093 & 0.107 & -0.162 & -0.234 \\
\hline & {$[0.39]$} & {$[0.6]$} & {$[-0.74]$} & {$[-0.98]$} \\
\hline \multirow[t]{2}{*}{ Tgt Market-to-Book } & -0.037 & -0.068 & 0.029 & 0.027 \\
\hline & {$[-0.4]$} & {$[-0.76]$} & {$[0.23]$} & {$[0.22]$} \\
\hline \multirow[t]{2}{*}{ Ln(Acq Total Assets) } & -0.001 & $0.321^{*}$ & -0.152 & -0.159 \\
\hline & {$[-0.01]$} & {$[1.76]$} & {$[-1.23]$} & {$[-0.83]$} \\
\hline \multirow[t]{2}{*}{ Ln(Tgt Total Assets) } & -0.089 & -0.098 & -0.001 & 0.005 \\
\hline & {$[-1.15]$} & {$[-1.41]$} & {$[-0.01]$} & {$[0.06]$} \\
\hline \multirow[t]{2}{*}{ Ln(Transaction Value) } & 0.12 & 0.087 & -0.009 & -0.026 \\
\hline & {$[1.53]$} & {$[1.2]$} & {$[-0.12]$} & {$[-0.36]$} \\
\hline \multirow[t]{2}{*}{ Tgt ROA } & -0.001 & -0.002 & -0.001 & 0.000 \\
\hline & {$[-0.37]$} & {$[-0.67]$} & {$[-0.14]$} & {$[0.08]$} \\
\hline \multirow[t]{2}{*}{ High/Low premium } & 0.087 & 0.091 & 0.108 & 0.093 \\
\hline & {$[0.78]$} & {$[0.78]$} & {$[0.70]$} & {$[0.60]$} \\
\hline \multirow[t]{2}{*}{ Ln(Acq Past year return) } & 0.03 & -0.103 & -0.122 & -0.146 \\
\hline & {$[0.2]$} & {$[-0.67]$} & {$[-0.57]$} & {$[-0.60]$} \\
\hline \multirow[t]{2}{*}{ Ln(Acq Past year return volatility) } & 0.261 & 0.343 & -0.339 & -0.161 \\
\hline & {$[0.54]$} & {$[0.58]$} & {$[-0.56]$} & {$[-0.27]$} \\
\hline \multirow[t]{2}{*}{ Acq Tobin Q } & -0.195 & -0.248 & -0.006 & -0.092 \\
\hline & {$[-0.77]$} & {$[-1.04]$} & {$[-0.02]$} & {$[-0.33]$} \\
\hline \multirow[t]{2}{*}{$\operatorname{Ln}(G D P)$} & -1.125 & -2.211 & -1.02 & -1.634 \\
\hline & {$[-0.41]$} & {$[-0.77]$} & {$[-0.26]$} & {$[-0.44]$} \\
\hline \multirow[t]{2}{*}{ Constant } & 5.558 & 6.631 & 7.305 & 10.58 \\
\hline & {$[0.41]$} & {$[0.50]$} & {$[0.40]$} & {$[0.60]$} \\
\hline Number of observations & 707 & 707 & 707 & 707 \\
\hline Adj. R-squared (\%) & 2.0 & 17.3 & 4.0 & 13.7 \\
\hline Year fixed effects & No & Yes & No & Yes \\
\hline Firm fixed effects & Yes & Yes & Yes & Yes \\
\hline
\end{tabular}


Table 4: Calendar-time portfolio regression using the Carhart four-factor model

\begin{tabular}{|c|c|c|c|c|c|c|c|c|}
\hline & \multicolumn{5}{|l|}{ Factor } & \multicolumn{3}{|c|}{ Model Characteristics } \\
\hline & Alpha & RMRF & SMB & HML & WML & Adj. R square & F-stat & Sig. \\
\hline \multicolumn{9}{|l|}{12 Months } \\
\hline Beta & -0.0035 & 0.0001 & -0.0002 & -0.0002 & 0.0002 & & & \\
\hline t-Statistics & -5.95 & 5.78 & -2.11 & -3.44 & 7.03 & 0.0325 & 18.76 & 0.00 \\
\hline Sig. & 0.000 & 0.000 & 0.035 & 0.001 & 0.000 & & & \\
\hline \multicolumn{9}{|l|}{24 Months } \\
\hline Beta & -0.0014 & 0.0001 & -0.0004 & -0.0001 & 0.0001 & & & \\
\hline t-Statistics & -3.24 & 4.62 & -7.16 & -1.68 & 4.01 & 0.0604 & 19.93 & 0.00 \\
\hline Sig. & 0.001 & 0.000 & 0.000 & 0.092 & 0.000 & & & \\
\hline \multicolumn{9}{|l|}{36 Months } \\
\hline Beta & -0.0024 & 0.0001 & -0.0003 & 0.0000 & 0.0001 & & & \\
\hline t-Statistics & -6.42 & 5.21 & -5.27 & -0.93 & 4.35 & 0.0742 & 14.19 & 0.00 \\
\hline Sig. & 0.000 & 0.000 & 0.000 & 0.351 & 0.000 & & & \\
\hline \multicolumn{9}{|l|}{60 Months } \\
\hline Beta & -0.002 & 0.000 & 0.000 & 0.000 & 0.000 & & & \\
\hline t-Statistics & -5.74 & 1.02 & -2.99 & -1.81 & 0.34 & 0.0935 & 4.30 & 0.00 \\
\hline Sig. & 0.000 & 0.306 & 0.003 & 0.071 & 0.731 & & & \\
\hline
\end{tabular}

